\title{
Estimation of Age Using Mandibular Permanent First Molars in Panoramic Radiographs in a Sample of Egyptian Population
}

\author{
Amira A. Wahdan, Heba I. Lashin, Mohammed O. Elborae
}

\begin{tabular}{|c|c|}
\hline & ABSTRACT \\
\hline $\begin{array}{l}\text { KEYWORDS } \\
\text { Identification, } \\
\text { Orthopantomographs, } \\
\text { Crown, } \\
\text { Coronal pulp, } \\
\text { Tooth coronal index. }\end{array}$ & 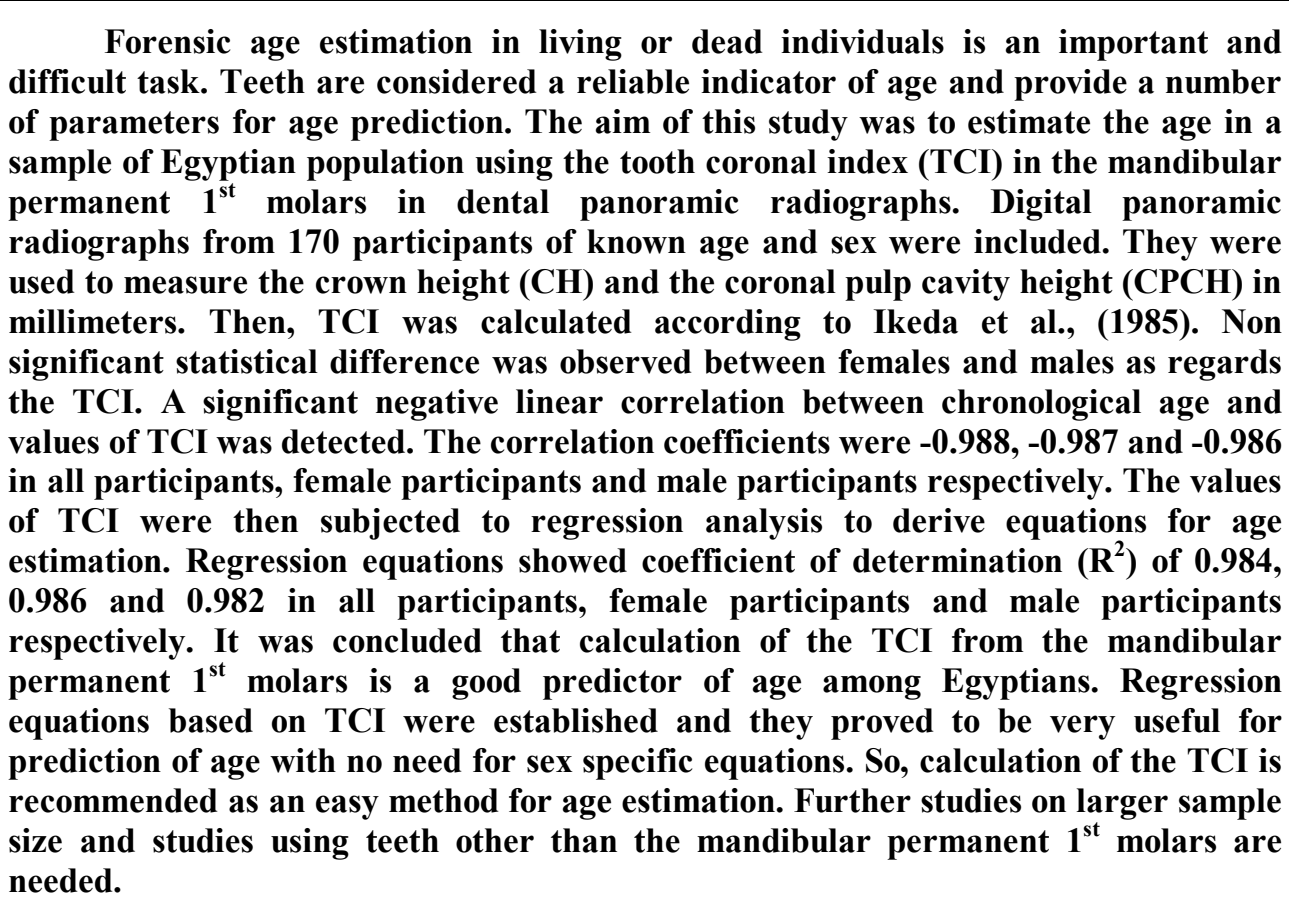 \\
\hline
\end{tabular}

\section{Introduction}

Identification is the establishment of a person's individuality and estimation of age is

\footnotetext{
Amira A. Wahdan

Department of Forensic Medicine and Clinical Toxicology, Faculty of Medicine, Tanta University

E-mail:dr.awahdan@yahoo.com

Heba I. Lashin

Department of Forensic Medicine and Clinical Toxicology, Faculty of Medicine, Tanta University

Mohammed O. Elborae

Department of Oral Medicine, Periodontology, Oral Diagnosis and Radiology, Faculty of Dentistry, Tanta University
}

one of its crucial criteria. Forensic age estimation in living or dead individuals is an important and difficult task. Finding an accurate and dependable method to determine age, especially in adults, has become increasingly important (Cameriere et al., 2004; Saxena, 2011; Acharya and Sivapathasundharam, 2012).

Teeth were found to be the most durable and least body parts affected by post-mortem changes. Teeth are resistant to different external influences, mechanical, chemical and thermal insults. It is also observed that tooth development is not perceptibly affected by 
diseases, drugs, endocrine status as compared to bone, consequently making them the preferred tissue in forensic investigations (Morse et al., 1991; Maber et al., 2006; Cameriere et al., 2007).

Teeth are considered a reliable indicator of age and provide a number of parameters for age prediction (Babshet et al., 2011). Dental age estimation is based on morphological, histological, biochemical and radiological assessment of teeth (Willems, 2001). Dental age prediction in adults is usually done using a number of methods including Gustafson's parameters, Johanson's grading, dental translucency, and cementum annulations. Other studies based on amino acid racemization and dental nuclear tests (Zaher et al., 2011). However, these methods are destructive and require extraction of teeth which is unethical and not feasible in living individuals (Bosmans et al., 2005).

Radiograph is a less invasive technique, which can be utilized in both living and dead persons. Dental orthopantomogram has been employed as a helpful tool in forensic medicine. Digital panoramic images have important advantages including; broad coverage, minimal radiation exposure and the brief time frame required for obtaining images (Razi et al., 2009).

The aim of this study was to estimate the age in a sample of Egyptian population based on the relationship between age and measurement of the tooth coronal index (TCI) in the mandibular permanent $1^{\text {st }}$ molars in dental panoramic radiographs and to develop regression equations that can be used in Egyptians.

\section{Material and Method}

The orthopantomogramic sample used in this study was digital panoramic radiographs of good to excellent quality. They were collected from 170 participants of known age and sex
(86 female and 84 male) who visited the Department of Oral Medicine, Periodontology, Oral Diagnosis and Radiology, Faculty of Dentistry, Tanta University. The orthopantomographs were taken as a part of the participants' routine treatment.

\section{Inclusion criteria}

- The selected participants were Egyptians.

- The selected tooth on the orthopantomograph was the mandibular permanent $1^{\text {st }}$ molar because mandibular teeth are more visible than the maxillary ones. The selected mandibular permanent $1^{\text {st }}$ molar is of any one side (right or left) where the pulp chamber was more visible as the difference between the right and the left teeth is statistically insignificant (Drusini et al., 1997; Igbigbi and Nyirenda, 2005).

\section{Exclusion criteria}

- Tooth with any pathology such as caries that alter the surface area of tooth.

- Badly destructed tooth.

- Filled tooth or any prosthetic crown.

- Root-filled tooth.

The measurements were done by an expert dentist with the SIDEXIS-XG 2.52 software (by Sirona ${ }^{(}$dental system $\mathrm{GmbH}$ ) for accuracy and precision. This software allows linear as well as curvilinear measurements between any two points or multiple points.

As shown in figure 1, straight line traced between the cemento-enamel junctions is the division between the anatomical crown and root (cervical line). The crown height $(\mathrm{CH})$ was measured vertically from the cervical line to the tip of the highest cusp following Moss et al. (1967). The coronal pulp cavity height $(\mathrm{CPCH})$ was measured vertically from the cervical line to the tip of the highest pulp horn after Ikeda et 
al. (1985). The tooth-coronal index (TCI) was then calculated as follows: $\mathrm{TCI}=\mathrm{CPCH} \times$ 100/CH (Ikeda et al., 1985). The use of an index obviates the need to standardize the tooth size on the photographs.

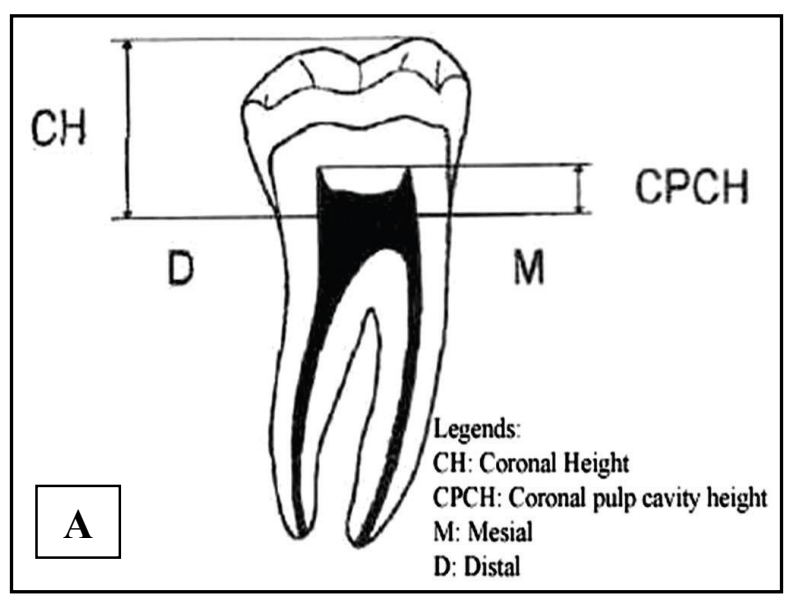

Fig. (1): A: Schematic representation of the measurements taken. The straight line traced between the distal (D) and mesial (M) enamel represents the division between the anatomical crown and root (cervical line). $\mathrm{CH}=$ (coronal height); $\mathrm{CPCH}=$ (coronal pulp cavity height). $\mathrm{B}$ : A part of panoramic radiograph showing the measurements.

\section{Statistical analysis}

The collected data were organized and statistically analyzed using SPSS software statistical computer package for windows version 22. For quantitative data, the ShapiroWilk test for normality was performed. For data that were not normally distributed median and interquartile range (expressed as $25^{\text {th }}-75^{\text {th }}$ percentiles) were calculated and MannWhitney test was used for comparison between independent groups while Wilcoxon signed rank test was used to compare related samples. Spearman's correlation was performed. For normally distributed data, values were expressed as mean and standard deviation and independent sample $t$ test was used for comparison between independent groups. For qualitative data, Pearson's Chi-square was used. Simple Linear regression analysis was
The measurements were taken to the nearest $0.01 \mathrm{~mm}$. Then they were stored along with the captured image for further identification and reference.

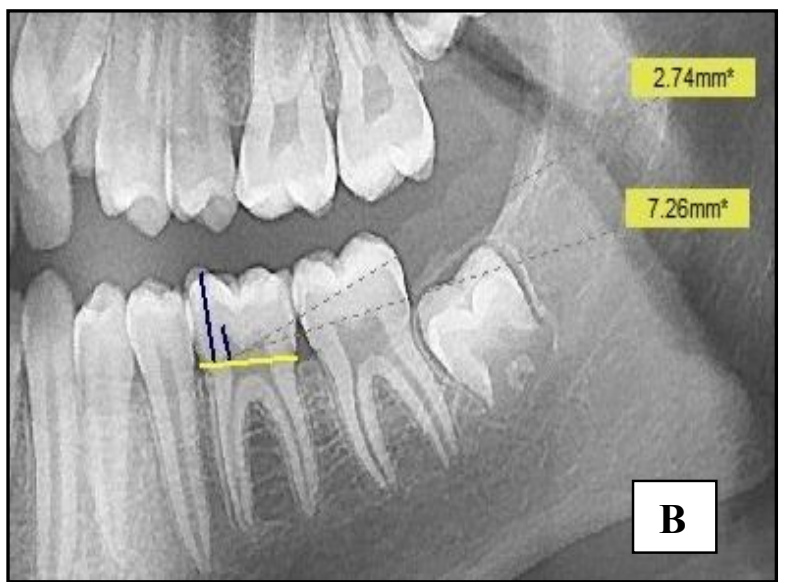

employed to calculate an equation for prediction of age using TCI in females and males. Significance was adopted at $p<0.05$ for interpretation of results of tests (Dawson and Trapp, 2001).

\section{Results}

The present study included ortho pantomographs from 170 participants of known age and sex ( 86 female and 84 male). Their chronological age (real age) ranged between 6 and 60 years with a median of 24 years (Inter Quartile Range 'IQR' 13 and 41). The median chronological age for female participants was 22 years (IQR 14 and 42), while that of males was 27 years (IQR 11.5 and 41). Table (1) shows the number of male and female participants in each age group. 
Table (1): Sex distribution in different age groups $(n=170)$.

\begin{tabular}{|c|c|c|c|c|c|c|c|c|c|}
\hline & \multicolumn{6}{|c|}{ Sex } & \multicolumn{2}{|c|}{$\begin{array}{c}\text { Pearson's Chi } \\
\text { Square Test }\end{array}$} \\
\hline & & \multicolumn{2}{|c|}{ Female } & \multicolumn{2}{|c|}{ Male } & \multicolumn{2}{|c|}{ Total } & \multirow{2}{*}{$X^{2}$} & \multirow{2}{*}{$\mathbf{P}$} \\
\hline & & n & $\%$ & $\mathbf{n}$ & $\%$ & n & $\%$ & & \\
\hline \multirow{7}{*}{ Age groups } & $\leq 10$ & 10 & $11.6 \%$ & 16 & $19 \%$ & 26 & $15.3 \%$ & \multirow{7}{*}{4.028} & \multirow{7}{*}{0.545} \\
\hline & $>10-20$ & 30 & $34.9 \%$ & 19 & $22.6 \%$ & 49 & $28.8 \%$ & & \\
\hline & $>20-30$ & 12 & $14 \%$ & 14 & $16.7 \%$ & 26 & $15.3 \%$ & & \\
\hline & $>30-40$ & 12 & $14 \%$ & 12 & $14.3 \%$ & 24 & $14.1 \%$ & & \\
\hline & $>40-50$ & 11 & $12.8 \%$ & 12 & $14.3 \%$ & 23 & $13.5 \%$ & & \\
\hline & $>50-60$ & 11 & $12.8 \%$ & 11 & $13.1 \%$ & 22 & $12.9 \%$ & & \\
\hline & Total & 86 & $100 \%$ & 84 & $100 \%$ & 170 & $100 \%$ & & \\
\hline
\end{tabular}

$\mathrm{n}=$ number

The median of $\mathrm{CH}$, TCI and the mean \pm standard deviation of $\mathrm{CPCH}$ for both sexes are shown in table (2). There was a significant statistical difference between females and males as regards $\mathrm{CH}$ only, while there was no significant difference as regards $\mathrm{CPCH}$ and TCI. Furthermore, the median of $\mathrm{CH}, \mathrm{CPCH}$ and the mean \pm standard deviation of TCI for all age groups are shown in table (3).

Table (2): Comparison of coronal height, coronal pulp cavity height and tooth coronal index in between female and male participants $(\mathrm{n}=170)$.

\begin{tabular}{|c|c|c|c|c|c|}
\hline & \multicolumn{2}{|c|}{ Sex } & \multicolumn{2}{|c|}{ Test of Significance } \\
\hline & & $\begin{array}{l}\text { Female } \\
(n=86)\end{array}$ & $\begin{array}{c}\text { Male } \\
(n=84)\end{array}$ & Statistic test & $\mathbf{P}$ \\
\hline \multirow{3}{*}{$\mathrm{CH}(\mathbf{m m})$} & Minimum - Maximum & $3.60-8.60$ & $3.66-10.37$ & \multirow{3}{*}{$\mathrm{Z}_{\mathrm{MW}}=2.619$} & \multirow{3}{*}{$0.009 *$} \\
\hline & Median & 6.70 & 7.00 & & \\
\hline & IQR & $6.10-7.20$ & $6.32-7.70$ & & \\
\hline \multirow{3}{*}{ СРCH (mm) } & Minimum - Maximum & $0.54-3.34$ & $0.84-4.23$ & \multirow{3}{*}{$\mathrm{t}=-1.260$} & \multirow{3}{*}{0.209} \\
\hline & Mean & 2.22 & 2.22 & & \\
\hline & Standard deviation & 0.64 & 0.76 & & \\
\hline \multirow{3}{*}{ TCI (\%) } & Minimum - Maximum & $14.46-45.20$ & $15.03-46.70$ & \multirow{3}{*}{$Z_{\mathrm{MW}}=0.298$} & \multirow{3}{*}{0.766} \\
\hline & Median & 33.97 & 31.96 & & \\
\hline & IQR & $23.77-38.96$ & $24.19-40.10$ & & \\
\hline
\end{tabular}

$\mathrm{CH}=$ coronal height; $\mathrm{CPCH}=$ coronal pulp cavity height; $\mathrm{TCI}=$ tooth coronal index; $\mathrm{n}=$ number; $\mathrm{IQR}=$ interquartile range; $\mathrm{ZMW}=$ Mann-Whitney test; $\mathrm{t}=$ Independent samples $\mathrm{t}$ test; * significant. 
Table (3): Comparison of coronal height, coronal pulp cavity height and tooth coronal index in different age groups $(n=170)$.

\begin{tabular}{|l|c|c|c|c|c|c|c|c|c|}
\hline \multirow{2}{*}{$\begin{array}{c}\text { Age } \\
\text { groups }\end{array}$} & \multicolumn{4}{|c|}{ CH (mm) } & \multicolumn{3}{c|}{ CPCH (mm) } & \multicolumn{3}{c|}{ TCI (\%) } \\
\cline { 2 - 10 } & $\begin{array}{c}\text { Minimum } \\
\text { Maximum }\end{array}$ & Median & IQR & $\begin{array}{c}\text { Minimum } \\
- \\
\text { Maximum }\end{array}$ & Median & IQR & $\begin{array}{c}\text { Minimum } \\
- \\
\text { Maximum }\end{array}$ & Mean & $\begin{array}{c} \pm \\
\text { SD }\end{array}$ \\
\hline$\leq \mathbf{1 0}$ & $\begin{array}{c}4.54- \\
10.37\end{array}$ & 6.86 & $\begin{array}{c}6.23- \\
7.73\end{array}$ & $2.12-4.23$ & 2.98 & $\begin{array}{c}2.62- \\
3.25\end{array}$ & $\begin{array}{c}39.77- \\
46.70\end{array}$ & 42.72 & 1.81 \\
\hline$>\mathbf{1 0 - 2 0}$ & $3.60-8.21$ & 6.98 & $\begin{array}{c}6.34- \\
7.46\end{array}$ & $1.43-3.32$ & 2.72 & $\begin{array}{c}2.45- \\
2.93\end{array}$ & $\begin{array}{c}35.29- \\
42.13\end{array}$ & 38.99 & 1.59 \\
\hline$>\mathbf{2 0 - 3 0}$ & $3.66-8.11$ & 6.52 & $\begin{array}{c}6.06- \\
6.94\end{array}$ & $1.20-2.75$ & 2.12 & $\begin{array}{c}1.92- \\
2.29\end{array}$ & $\begin{array}{c}30.21- \\
34.64\end{array}$ & 32.51 & 1.25 \\
\hline$>\mathbf{3 0 - 4 0}$ & $5.24-9.53$ & 7.02 & $\begin{array}{c}6.42- \\
7.73\end{array}$ & $1.50-2.90$ & 1.92 & $\begin{array}{c}1.65- \\
2.09\end{array}$ & $\begin{array}{c}24.77- \\
30.43\end{array}$ & 26.94 & 1.71 \\
\hline$>\mathbf{4 0 - 5 0}$ & $5.57-8.21$ & 7.09 & $\begin{array}{c}6.61- \\
7.38\end{array}$ & $1.23-1.88$ & 1.58 & $\begin{array}{c}1.45- \\
1.68\end{array}$ & $\begin{array}{c}19.85- \\
24.61\end{array}$ & 22.44 & 1.23 \\
\hline$>\mathbf{5 0 - 6 0}$ & $3.66-7.87$ & 6.30 & $\begin{array}{c}5.86- \\
6.77\end{array}$ & $0.54-1.51$ & 1.09 & $\begin{array}{c}0.98- \\
1.24\end{array}$ & $\begin{array}{c}14.46- \\
19.91\end{array}$ & 17.12 & 1.69 \\
\hline
\end{tabular}

$\mathrm{CH}=$ coronal height; $\mathrm{CPCH}=$ coronal pulp cavity height; $\mathrm{TCI}=$ tooth coronal index; $\mathrm{IQR}=$ Interquartile range; $\mathrm{SD}=$ standard deviation

Results of correlation between chronological age and values of TCI, showed a significant and strong negative linear correlation in all participants (whole study

population), female participants and male participants with calculated Spearman's rho correlation coefficient of $-0.988,-0.987$ and 0.986 respectively (Table 4).

Table (4): Spearman's correlation between age and tooth coronal index (TCI)

\begin{tabular}{|c|c|c|c|c|}
\hline \multicolumn{2}{|c|}{} & \multicolumn{3}{|c|}{ Age } \\
\hline \multicolumn{2}{|c|}{ Spearman's Correlation } & In all participants & In females & In males \\
\hline \multirow{2}{*}{ TCI } & $\mathrm{r}_{\mathrm{s}}$ & -0.988 & -0.987 & -0.986 \\
\cline { 2 - 5 } & $\mathrm{P}$ & $<0.001^{*}$ & $<0.001^{*}$ & $<0.001^{*}$ \\
\hline
\end{tabular}

$r_{s}=$ Spearman's rho correlation coefficient; * significant.

A linear regression for predicting age based on TCI was done (Table 5). This linear regression established that TCI could significantly predict age in years.

For all participants (whole study population); $\mathrm{F}=10241.794, \mathrm{p}<0.001$ and TCI accounted for $98.4 \%$ of the explained variability in age.
For females; $\mathrm{F}=5885.739, \mathrm{p}<0.001$ and TCI accounted for $98.6 \%$ of the explained variability in age.

For males; $\mathrm{F}=4513.885, \mathrm{p}<0.001$ and TCI accounted for $98.2 \%$ of the explained variability in age. 
Table (5): Linear regression predicting age based on tooth coronal index (TCI)

\begin{tabular}{|c|c|c|c|c|c|c|c|c|}
\hline & \multirow{2}{*}{$\mathbf{B}_{0}$} & \multirow{2}{*}{$\mathbf{B}_{1}$} & \multirow{2}{*}{ SE $B_{1}$} & \multicolumn{2}{|c|}{$\begin{array}{l}\text { 95\% Confidence } \\
\text { interval for B1 }\end{array}$} & \multicolumn{2}{|c|}{$\begin{array}{c}\text { ANOVA test of model } \\
\text { coefficients }\end{array}$} & \multirow{2}{*}{$\begin{array}{l}\text { Adjusted } \\
\text { R square }\end{array}$} \\
\hline & & & & $\begin{array}{l}\text { Lower } \\
\text { bound }\end{array}$ & $\begin{array}{l}\text { Upper } \\
\text { bound }\end{array}$ & $\mathbf{F}$ & $\mathbf{P}$ & \\
\hline $\begin{array}{l}\text { All } \\
\text { participants }\end{array}$ & 85.45 & -1.82 & 0.18 & -1.853 & -1.782 & 10241.794 & $<0.001^{*}$ & 0.984 \\
\hline Females & 84.96 & -1.80 & 0.002 & -1.846 & -1.753 & 5885.739 & $<0.001 *$ & 0.986 \\
\hline Males & 85.91 & -1.835 & 0.027 & -1.889 & -1.781 & 4513.885 & $<0.001 *$ & 0.982 \\
\hline
\end{tabular}

$\mathrm{B}_{0}=$ Unstandardized Coefficient of constant; $\mathrm{B}_{1}=$ Unstandardized Coefficient of model (using TCI); SE $\mathrm{B}_{1}=$ standard error of $\mathrm{B}_{1}$; * significant.

The resulting regression equations of age estimation (Figures 2 and 3 ) were then established as follows: Predicted age (years) $=$ $\mathrm{b}_{0}+\left(\mathrm{b}_{1} \mathrm{x} \mathrm{TCI}\right)$.

For all participants (whole study population):

TCI).

\section{Predicted age $($ years $)=85.45+(-1.82 \times \quad$ TCI $)$.}

For females:

Predicted age $($ years $)=84.96+(-1.80$ $\mathrm{x}$ TCI).

For males:

Predicted age $($ years $)=85.91+(-1.84 \mathrm{x}$

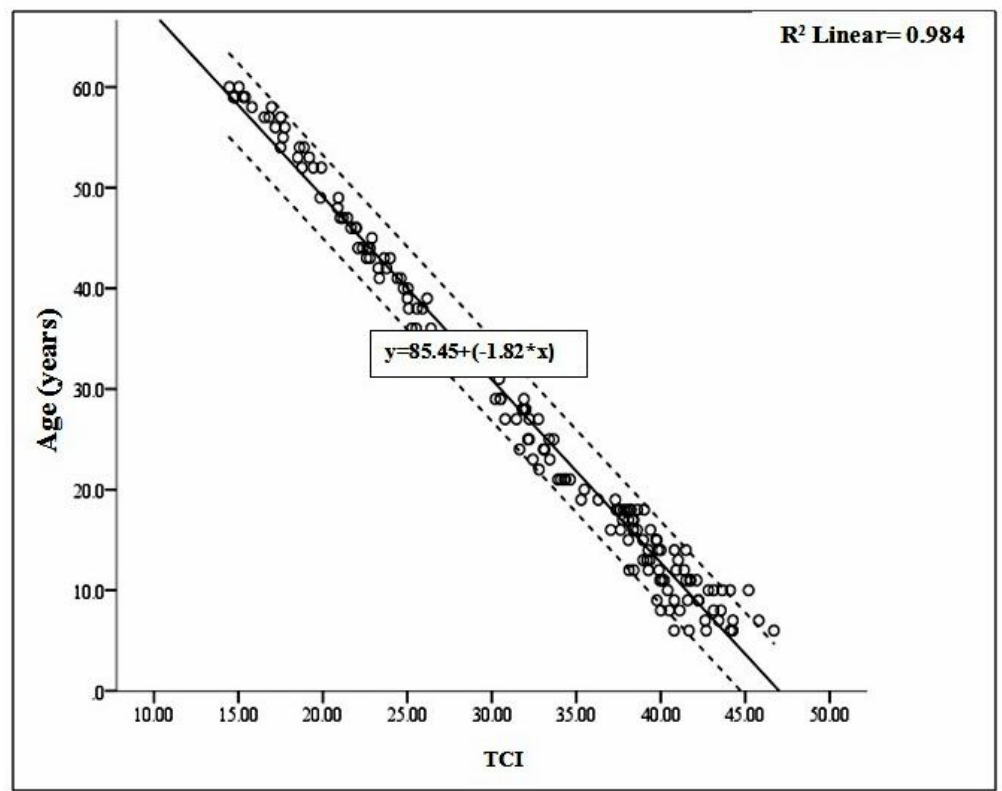

Fig. (2): A scatterplot representing the relationship between age (in years) and tooth coronal index (TCI) in all participants. The solid line represents the best line of fit of linear regression while interrupted lines represent confidence intervals. The equation to predict age from TCI measurement is illustrated where $\mathrm{y}=$ age and $\mathrm{x}=\mathrm{TCI}$. 

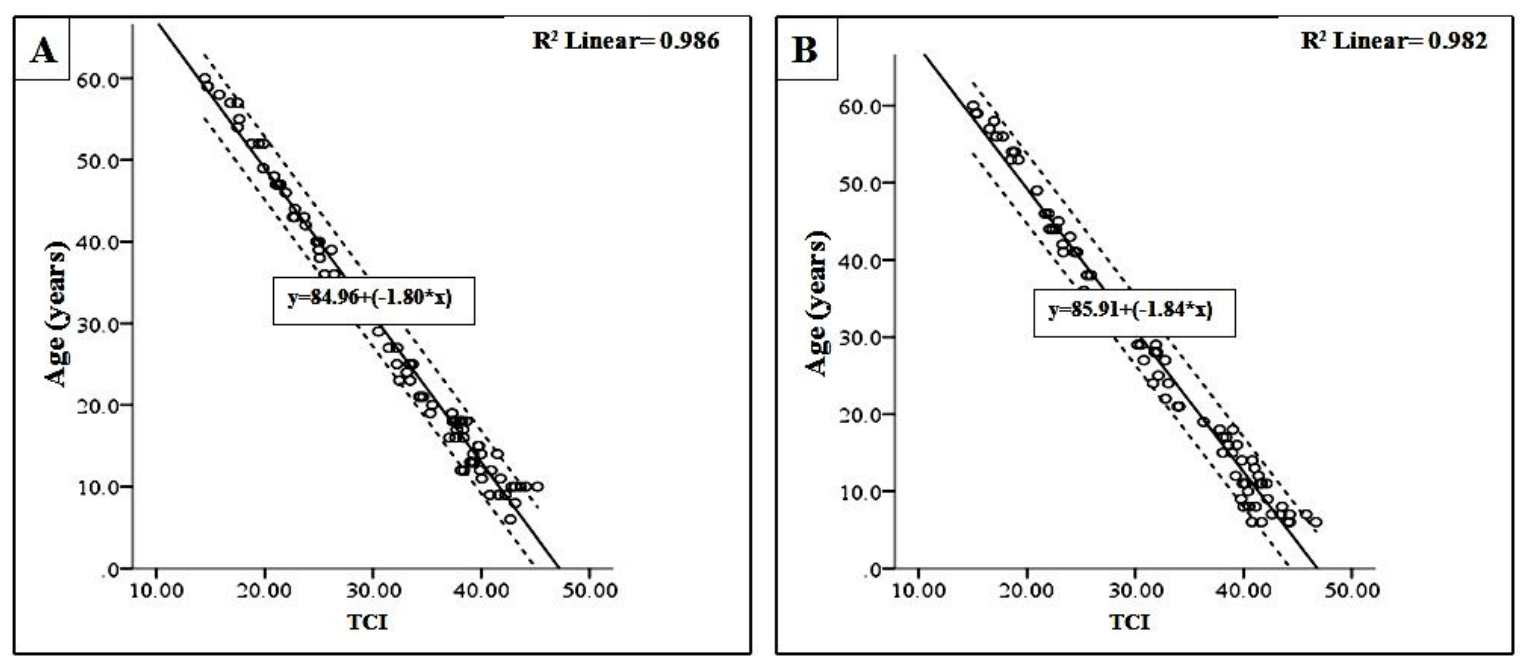

Fig. (3): A scatterplot representing the relationship between age (in years) and tooth coronal index (TCI). A: in female participants and B: in male participants. The solid line represents the best line of fit of linear regression while interrupted lines represent confidence intervals. The equation to predict age from TCI measurement is illustrated where $\mathrm{y}=$ age and $\mathrm{x}=$ TCI.

A comparison between the real age and the predicted age using TCI values were done (Table 6). It revealed that the real age and the predicted age were more or less similar (with

non-significant difference) in the whole study population, in females and in males which mean that the equations calculated are very useful for predicting age using the TCI.

Table (6): Comparison between real age and predicted age in all participants, female participants and male participants

\begin{tabular}{|c|c|c|c|c|c|c|c|}
\hline & \multicolumn{2}{|c|}{ All participants } & \multicolumn{2}{|c|}{ Females } & \multicolumn{2}{|c|}{ Males } \\
\hline & & $\begin{array}{c}\text { Real } \\
\text { Age }\end{array}$ & Predicted age & Real Age & Predicted age & Real Age & Predicted age \\
\hline \multicolumn{2}{|c|}{ Median (years) } & 24.0 & 25.5 & 22.0 & 23.8 & 27.0 & 27.1 \\
\hline \multirow{2}{*}{$\begin{array}{l}\text { Wilcoxon } \\
\text { signed rank } \\
\text { test }\end{array}$} & $\mathbf{Z}$ & \multicolumn{2}{|r|}{-0.518} & \multicolumn{2}{|r|}{0.144} & \multicolumn{2}{|c|}{-0.818} \\
\hline & $\mathbf{P}$ & \multicolumn{2}{|r|}{0.604} & \multicolumn{2}{|r|}{0.885} & \multicolumn{2}{|c|}{0.413} \\
\hline
\end{tabular}

\section{Discussion}

Age estimation is crucial in legal situations whether involving living persons or dead persons or even remains in crimes, mass disasters and war infringement (Schmeling et al., 2007).
Teeth are the most frequently used for identification and age estimation when skeletal remains are in poor condition as they are more resistant to peri- and post-mortem changes. Furthermore, teeth can be examined clinically and radiographically with low patient radiation dose (Jeevan et al., 2011). 
In the most recent decade, various new techniques for age estimation from teeth have been created and existing strategies have been refined. These techniques claim relatively precise estimates (Babshet et al., 2011). One of those techniques is TCI that was previously calculated according to Ikeda et al. (1985).

The current study for age estimation was conducted using panoramic radiographs. This technique offers the possibility and advantage of evaluation of all teeth and their required measurements on a single radiograph. In addition, a digital orthopantomograph can be acquired using a standard technique with high reproducibility, while the acceptability of intraoral radiographs is dependent on the techniques used and the practical training of the personnel (Chandramala et al., 2012).

In the present study the mandibular permanent $1^{\text {st }}$ molar teeth were selected based on a previous study (Igbigbi and Nyirenda, 2005) which showed that this tooth is among those which are most strongly correlated with age. In addition, they found no significant difference between teeth from right and left side of the jaw. Consequently, teeth from either right or left side were chosen according to which side is more suitable for measurements (the pulp chamber is more visible).

One hundred and seventy orthopantomographs from participants of known age and sex were included in the present study. It was revealed that there is no statistically significant difference between both sexes as regards the TCI. This went hand in hand with results of previous studies done by Drusini (2008) in Italy, Karkhanis et al. (2013) in Western Australia, Shrestha (2014) in Nepal and El Morsi et al. (2015) in Egypt. All of them stated that the sex of the individual appears to have no significant effect on age estimation and so, sex specific formulae are not necessary for age estimation in specimens of unknown sex. On the other side this result disagreed with that of Igbigbi and Nyirenda (2005) in Malawi and Agematsu et al. (2010) in Japan who reported that gender has a significant influence on age estimation using TCI and hence there is need for sex specific formulae. They explained this difference by the influence of estrogen on the formation of secondary dentin.

In this study, a significant and strong negative linear correlation between chronological age and values of TCI was revealed (this means that increase in age, will lead to decrease in the TCI). The calculated spearman's rho correlation coefficients were $0.988,-0.987$ and -0.986 in all participants, female participants and male participants respectively. This negative correlation could be explained by Landa et al. (2009) who reported that there is reduction of the size of dental pulp cavity as a result of secondary dentin deposition with increasing age. This regression change, apart from morphological techniques, can also be analyzed by radiological techniques.

This result was consistent with result obtained by Igbigbi and Nyirenda (2005) who found a significant negative correlation between age and TCI. Correlation coefficient of all participants, female participants and male participants were $-0.735,-0.650$ and 0.799 respectively. In addition, Drusini (2008) also found high degree of negative correlation between age and TCI. Correlation coefficients for all participants, female participants and male participants were $-0.90,-0.87$ and -0.92 respectively. Furthermore, negative correlation between age and TCI was reported by Karkhanis et al. (2013) with correlation coefficients of $-0.043,-0.198$ and -0.026 for all participants, female participants and male participants respectively. However this correlation was a weak one.

On the other hand, El Morsi et al. (2015) found a weak positive correlation between age and TCI. They reported correlation 
coefficients of $0.157,0.172$ and 0.138 for the right $1^{\text {st }}$ molar and $0.197,0.245$ and 0.146 for the left $1^{\text {st }}$ molar in all participants of their study, female participants and male participants respectively. However this positive correlation was not found elsewhere in the literature except in the study done by Shrestha (2014).

A linear regression for predicting age based on TCI was done in the current study. This linear regression established that TCI could significantly predict age in years; TCI accounted for $98.4 \%, 98.6 \%$ and $98.2 \%$ of the explained variability in age for all participants, for female and for male participants respectively. Regression equations were then established. For all participants; the equation was as follow; predicted age (years) $=85.45+$ $(-1.82 \mathrm{x}$ TCI). For females; predicted age $($ years $)=84.96+(-1.80 \times \mathrm{TCI})$, while for males; predicted age $($ years $)=85.91+(-1.84 \mathrm{x}$ TCI).

This was partially in accordance with Drusini (2008) who found that TCI accounted for $82 \%, 77 \%$ and $85 \%$ of the explained variability in age for all participants, for female and for male participants respectively. He established both sex specific and non specific regression equations for prediction of age. For all participants of their study the equation was as follows; age $=76.073+(-$ $1.4576 \times \mathrm{TCI})$, for females; age $=73.846+(-$ $1.3906 \times \mathrm{TCI})$ and for males; age $=77.747+(-$ $1.5066 \times \mathrm{TCI})$. On contrary, Talabani et al. (2015) found that TCI accounted for $49 \%$ of the explained variability in age for all participants of their study and they developed a sex non specific equation as follows; predicted age $=3.78+(-0.064 \times \mathrm{TCI})$. Their study was on 96 orthopantomographs of Iraqian subjects.

A comparison between the median of the real age and the median of the predicted age using TCI values was done in this study and it revealed that there was non-significant difference between them in all, female and male participants. This finding was in agreement with Talabani et al. (2015) who found that for the whole sample of their study, the real age and the predicted age using TCI values were similar. The mean of the real age was 35.79 years, and the mean of the predicted age was 35.89 years. In addition, Drusini (2008) also found that the mean of the actual age and the mean of the estimated age using TCI values were more or less similar in whole sample population (39.7 and 36.68 years respectively), in females (39.21 and 35.83 years respectively) and in males (40.11 and 37.46 years respectively).

\section{Conclusion}

It is concluded that calculation of the TCI from the mandibular permanent $1^{\text {st }}$ molars is a good predictor of age among Egyptians. Regression equations based on TCI were established and they proved to be very useful for prediction of age. In addition, sex has no effect on TCI, and so there is no need for sex specific equations. This method has the advantages of being easy, non-invasive, time saving, applicable in both living and dead individuals and doesn't require highly specialized equipment.

\section{Recommendations}

Calculation of the TCI is recommended as an easy method for age estimation with no need for sex-specific equations. Further studies on larger sample size are needed. Studies using teeth other than the mandibular permanent $1^{\text {st }}$ molars to detect the extent of their accuracy for age prediction are also needed. Different environmental factors such as dietary habits, genetic background, and history of any illness or dentition related diseases should be taken in consideration to know their effect on the accuracy of age prediction. 


\section{References}

Acharya A.B.; Sivapathasundharam B. (2012): Shafer's Textbook of Oral Pathology, A. Rajendran and B. Sivapathasundharam (Eds.). $7^{\text {th }}$ Edition. Elsevier a division of Reed Elsevier India Private Limited, New Delhi, P.P. 879-910.

Agematsu H.; Someda H.; Hashimoto M.; et al. (2010): "Three-dimensional observation of decrease in pulp cavity volume using micro-CT: age-related change". The Bulletin of Tokyo Dental College, 51:1-6.

Babshet M.; Acharya A.B.; Naikmasur V.G. (2011): "Age estimation from pulp/tooth area ratio (PTR) in an Indian sample: A preliminary comparison of three mandibular teeth used alone and in combination". J. Forensic Leg. Med., 18:350-354.

Bosmans N.; Ann P.; Aly M.; Willems G. (2005): "The application of Kvaal's dental age calculation technique on panoramic dental radiographs". Forensic Sci. Int., 153:208-212.

Cameriere R.; Ferrante L.; Cingolani M. (2004): "Precision and reliability of pulp/tooth area ratio (RA) of second molar as indicator of adult age". J. Forensic Sci., 49:1319-1323.

Cameriere R.; Ferrante L.; Belcastro M.G.; et al. (2007): "Age estimation by pulp/tooth ratio in canines by periapical X-rays". J. Forensic Sci., 52:166-170.

Chandramala R.; Sharma R.; Khan M.; Srivastava A. (2012): "Application of Kvaal's technique of age estimation on digital panoramic radiographs". Dentistry, 2:142-149.

Dawson B.; Trapp R.G. (2001): Basic and Clinical Biostatistics, B. Dawson and R.G. Trapp (Eds.). $3^{\text {rd }}$ Edition.
McGrow Hill Medical Publishing Division, New York, P.P. 161-218.

Drusini A. (2008): "The coronal pulp cavity index: A forensic tool for age determination in human adults". Cuadernos de Medicina Forense, 14:235-249.

Drusini A. G.; Toso O.; Ranzato C. (1997): "The coronal pulp cavity index: a biomarker for age determination in human adults". Am. J. Phys. Anthropol., 103:353-363.

El Morsi D.; Rezk H.; Aziza A.; ElSherbiny M. (2015): "Tooth coronal pulp index as a tool for age estimation in Egyptian population". Journal of Forensic Science \& Criminology, 3:201-208.

Igbigbi P.; Nyirenda S.K. (2005): "Age estimation of Malawian adults from dental radiographs". West Afr. J. Med., 24:329-333.

Ikeda N.; Umetsu K.; Kashimura S.; et al. (1985): "Estimation of age from teeth with their soft X-ray findings". Nihon Hōigaku Zasshi, 39:244-250.

Jeevan M.; Kale A.D.; Angadi P.V.; Hallikerimath S. (2011): "Age estimation by pulp/tooth area ratio in canines: Cameriere's method assessed in an Indian sample using radiovisiography". Forensic Sci. Int., 204:209.e1-209.e5.

Karkhanis S.; Mack P.; Franklin D. (2013): "Age estimation standards for a Western Australian population using the coronal pulp cavity index". Forensic Sci. Int., 231:412.e1-412.e6.

Landa M.; Garamendi P.; Botella M.; Alemán I. (2009): "Application of the method of Kvaal et al. to digital orthopantomograms". Int. J. Legal Med., 123:123-128.

Maber M.; Liversidge H. M.; Hector M. P. (2006): "Accuracy of age estimation of 
radiographic methods using developing teeth". Forensic Sci. Int., 159:68- 73.

Morse D.R.; Esposito J.V.; Schoor R.S.; et al. (1991): "A review of aging of dental components and a retrospective radiographic study of aging of the dental pulp and dentin in normal teeth". Quintessence Int., 22:711-720.

Moss M.L.; Chase P.S.; Howes R.I. (1967): "Comparative odontometry of the permanent post-canine dentition of American Whites and Negroes". Am. J. Phys. Anthropol., 27:125-142.

Razi T.; Moslemzade S.H.; Razi S. (2009): "Comparison of linear dimensions and angular measurements on panoramic images taken with two machines". J. Dent. Res. Dent. Clin. Dent. Prospects, 3:7-10.

Saxena S. (2011): "Age estimation of indian adults from orthopantomographs". Braz. Oral Res., 25:225-229.

Schmeling A.; Geserick G.; Reisinger W.; Olze A. (2007): "Age estimation". Forensic Sci. Int., 165:178-181.
Shrestha M. (2014): "Comparative evaluation of two established age estimation Techniques (two histological and radiological) by Image analysis software using single tooth". J. Forensic Res., 5:237-242.

Talabani R. M.; Baban M. T.; Mahmood M. A. (2015): "Age estimation using lower permanent first molars on a panoramic radiograph: A digital image analysis". J. Forensic Dent. Sci., 7:158162.

Willems G. (2001): "A review of the most commonly used dental age estimation techniques". J. Forensic Odontostomatol., 19:9-17.

Zaher J. F.; Fawzy I. A.; Habib S. R.; Ali M. M. (2011): "Age estimation from pulp/tooth area ratio in maxillary incisors among Egyptians using dental radiographic images". J. Forensic Leg. Med., 18:62-65. 


\section{تقلير العمر باستخدام الأضراس الأولى اللدائمة بـالفك السفلي في الأشعه البانورامية في عينة من المصريين}

\section{أميرة أمين وهلدان* ؛ هبه ابراهيم لاشيز* ؛ محمد عمر البرعى*}

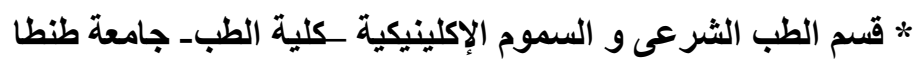

*قشم طب الفم وأمراض اللثة و طرق التثخيص و الأشعة _كلية طب الأسنان- جامعة طنطا

إن تقدير العمر من الوجهة الطبية الشرعية في الأشخاص الأحيـاء أو المتوفين هو مهمـة هامـة وصسبة. وتعتبر الأسنان مؤشر اللعمر يمكن الاعتماد عليه كماتوفر عددا من المعايير للتنبؤ بـالعمر. وقد كان هدف هذه هونه

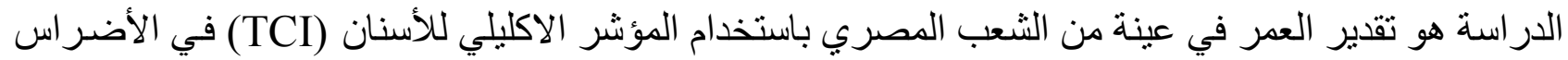

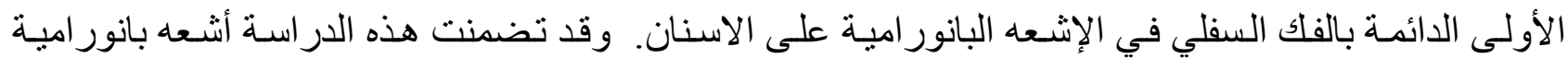
رقمية من • V ا مشارك معروفى العمر و الجنس. استخدمت هذه الاشعة في قياس ارتفاع التاج (CH) و ارتفاع الإن

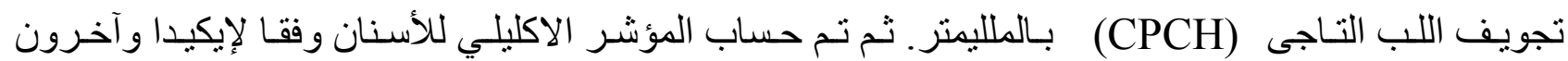
(910 ( ). وقد لوحظو جود فارق غير ذي دلاله احصائيه بين الذكور و الاناث بالنسبة للمؤشر الاكليلي للأسنان. و تم الكثف عن وجود علاقة خطية سلبية ذات دلالة إحصائية بين العمر الحقيقي وقيم المؤشر الاكليلي للأسنان.

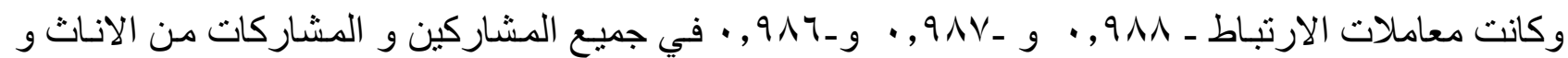

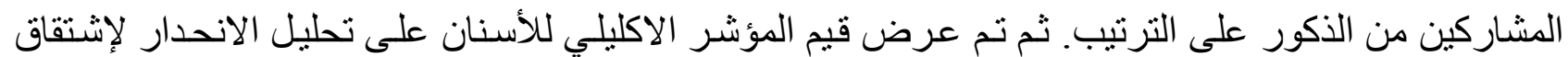

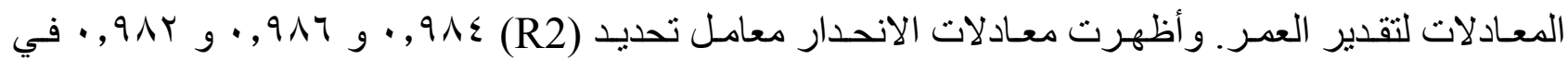

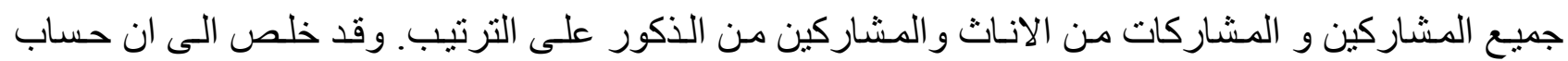

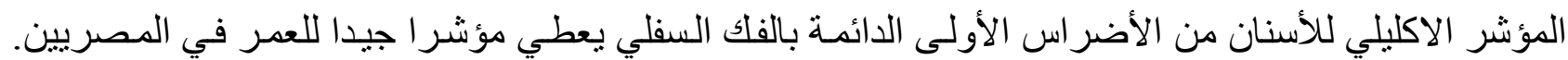

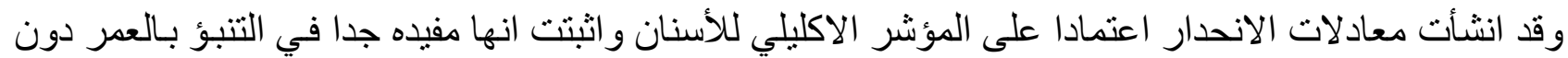
الحاجه للمعادلات الخاصة بالجنس. لذلك ينصح بحساب المؤشر الاكليلي للأسنان كطريقة سـهلة لتقدير العمر.

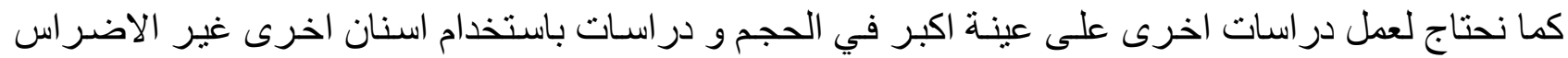
الاولى الدائمه بالفلك السفلي. 